\title{
Development Intelligent Web-based Learning System Using Object-Oriented Approach for Improving Innovative Thinking
}

\author{
Safaa S. Mahmoud
}

\begin{abstract}
This Paper aimed to study the techniques of object-oriented and UML as bases of modeling and development the e- learning system for improving innovative thinking. E-courses are not limited to mere content translation and extension, but contain instructional content, methods and delivery systems to provide an integrated educational environment that allows the student to trainee through learning activities, so this research concentrated on the way of implementation of the strategies to Internet education, and draw intelligent online e-courses management architecture. The researcher developed a strategy to achieve the proposed intelligent architecture for e-courses management (24/7) through Internet tools that can be achieved through activities and educational strategies $T h i s$ is in addition to the identification of (8) patterns of interaction within the educational site, was as follows: Learner-Learner Interactive, Learner-Instructor Interactive, Instructor-Learner Interactive, Learner-Content Interactive, Instructor-Content Interactive, Learner-Self Interactive, Learner-Interface Interactive, Learner-Tools Interactive
\end{abstract}

Index Terms-Web-based Learning System, ObjectOrientation, UML, e-course architecture.

\section{INTRODUCTION}

"The rapid development of the Internet technologies, especially the evolution of World Wide Web has led to tremendous growth in opportunities to teach and learn outside of the traditional classroom-based education. Over the past decade, the Internet has brought Web-based learning and offers many advantages: it is convenient, available at any time of the day, and can be accessed nearly anywhere in the world. Clearly, Web-based or distributed learning, offers a great potential to increase the availability and convenience of education. The problem domain of distance education system is quite complicated and involves many concepts such as course instructors, students, course materials, learning activities, etc. These concepts are also closely related to determine the structure of the system [1]". Object-oriented Approach has become popular in the software industry during the 1990s. This paper concentrated on learning and teaching activities using the components of learning rather than the course content design and structure or handling of communication infrastructure among several functions of web-based learning system [2].

In addition to the above exploratory study has shown that the status of e-courses in the Egyptian universities via the Internet at the present time as follows:

- E-courses system stand-alone application.
- E-course learning environment differ from traditional education, prompting the researcher to the need to search for a suitable education strategies, which may differ from the educational strategies used in traditional environments, in the methods, and in the ways of implementation.

The main research question is:

"What is the proposed web based learning system through intelligent architecture for e-courses management which is built on and the effectiveness of the proposed development in the innovative thinking among students?" This question divided into three sub questions as follows:

- What are the elements of the proposed intelligent architecture for e-courses management?

- What are the steps of building e-course in light of the proposed intelligent architecture for e-courses management using object oriented approach?

- What is the effectiveness of the e-course, which was built on the proposed intelligent architecture for ecourses management in the development of innovative thinking among students in educational technology?

The Research Limits:

- Only the application of current research on a group of students of the fourth year, at Department of educational Technology, Faculty of Specific Education, Ain Shams University, and who are studying computer networks course.

- Content was limited by to "LAN" computer networks, which is the task of teaching a fourth-technology education.

\section{Methodology}

A sample of (40) students were divided into two groups, the strength of each group (20) students, has been selected. Experimental design related to the first pilot study of the local network content through the Internet contains a traditional online course treatment; while the second related to the study through an educational website containing network e-course was to build on the proposed intelligent architecture for e-courses management using $\mathrm{OO}$.

http://www. Networks-course.com

http://www.e-learningcenter.com/free_aplus_course.htm 
EXPERIMENTAL DESIGN

\begin{tabular}{|c|l|}
\hline $\begin{array}{c}\text { Experimental } \\
\text { groups }\end{array}$ & $\begin{array}{c}\text { Experimental treatment } \\
\text { For Network course content }\end{array}$ \\
\hline $\begin{array}{c}\text { The first pilot } \\
\text { (15 students) }\end{array}$ & Traditional teaching method for the course \\
\hline $\begin{array}{c}\text { Second } \\
\text { experimental } \\
\text { group } \\
\text { (15 students }\end{array}$ & $\begin{array}{l}\text { Depends on the educational strategies \& } \\
\text { intelligent architecture for e-courses using OO }\end{array}$ \\
\hline
\end{tabular}

Current research adopted the Semi-experimental approach: which is used to determine the impact of the changing of the independent variable has been used to detect the relationship between the following variables:

- The independent variable: A proposed intelligent architecture for e-courses management using $\mathrm{OO}$ in the construction of the proposed e-courses.

- The dependent variable: Creative Thinking for students who use network e-courses.

The research procedures and tools are as follows:

- A survey of the literature and research related to the strategies of e-learning

- Identification of Internet tools that can be drawn upon the construction of the e-courses strategies.

- Identification of the Instructional design model that can be trusted in the design of the site of e-course.

- Develop a preliminary design of the proposed educational strategy in the light of the previous steps, in the light of the course content of networks.

- Building a Dynamic e-course.

- Building the necessary measurement tools to the site, this is a measure of innovative thinking of students: associated with the content and the e-course networks. (Prepared by the researcher)

- The final test to be conducted through the practical application of the two groups in the pilot study the experimental group during the first of its website contains a traditional network course, while studying the experimental group during the second website which contains an e-course had been prepared in the light of the proposed education strategy using OO.

\section{DEVELOPMENT INTELLIGENT WEB BASED LEARNING SYSTEM ARCHITECTURE REGARDING TO LEARNING STRATEGIES AND USING OO}

\section{A. Banai Theory in e-Learning Framework Environments:}

Elizabeth Stacy (2002) defined the Banai concept of knowledge through the Learners builds their own meaning from the perspective of knowledge. Learners are active in the educational process; they build their understanding through their interaction with the tools and the learning environment [3]. (Eugenia M.W.Ng \& Ada W.W.Ma, 2002) determined Banai trend as "the direction of allowing the most powerful ways in which educated them to change or enhance their understanding through talks, social, and access to them to express their ideas and listen to the ideas of the other [4]. The characteristics of the Internet multi-media, Hyper Text, hyperlinks, navigation support virtual learning environment which make it better than the traditional educational environment [5].

\section{B. E-Courses Learning Strategies}

The researcher reviewed some of the strategies of education via the Internet. The following set of educational strategies that can be used via the Internet, which was the synthesis between them to build the proposed intelligent architecture for e-courses management.

1) A Collaborative Learning Strategy:

Yi lee (2005) determined the application of cooperative learning strategy in the learning environments on the Internet is to pay the student to participate in educational activities, exchange of ideas, and interaction with the teacher, learning resources available, and find that one of the most important tools to achieve that strategy is on the Internet discussion forums.

\section{2) A Problem Solving Strategy:}

This strategy highlights the role of the learner as a key factor in the educational process, as the learner opportunity to create the appropriate types of activity to create mental, emotional, and directed towards the study of specific problem [6].

\section{3) Discussion Strategy}

It is the most preferred strategy among the educated adults, which rely on discussions among groups of learning, as it depends on the interaction and activity in the process of sharing learning among learners and help learners to acquire new expertise in the development of the subject of learning [7].

\section{4) Collaborative Learning Strategy:}

Participatory learning is a strategy for the education of learners working together in small groups or large, and shares in the accomplishment of the mission or to achieve common educational goals, with the acquisition of knowledge, skills or attitudes through collective action, in the learning process [8].

5) Active learning Strategy:

Berni Dodge (2000) determined that the active learning is not a new idea, but since a long time, the learning process is by nature a dynamic process dependent on reading, writing, listening and, most importantly, what distinguishes the active learning strategy is to leave the responsibility of organizing what they will learn educated learners themselves [9].

6) Learning strategy based on the project

It is based on the project as "a way of teaching the learner's mind filled in learning knowledge and skills through discovery and on the complex questions related to curriculum and build a final product to achieve the goal of learning through a series of tasks followed by the learner and the carefully designed by the teacher [10].

7) Interactive Electronic Lecture:

A multi-media packages and computer-based, as an integral part of the Electronic Course Delivery (ECD), transferred to the learners directly in the traditional lecture halls or at home, either online or on CD-ROM or available on the Internet at any time [7].

8) Visual Thinking Strategy:

Thinking and visual thinking strategy are based on the formulation of questions encouraging reflection and observation [11]. 
9) Discovery Learning Strategy:

The strategy aims to equip them with the skills of critical thinking, communication skills, problem solving, also aims to equip them with the skills of observation and creative.

This is the proposed and the best ways to obtain the understanding of learning as the learner in the position detection is an active learner, and acquire an effective and productive learning, and acquire the skills and research skills of observation and classification, prediction, measurement, interpretation, assessment, design and recording observations and interpretation of information, forming and testing hypotheses; as this Requests the learners use the senses, mind and intuition in the integration and coherence of knowledge to solve problems faced objectively[9].

The proposed intelligent architecture for e-courses management), which consist of (9) each of the services which refers to the educational strategy is working as an integrated educational interact and complement the rest of other services, has been the main strategy, which included all educational strategies within the strategy to be active learning.

TABLE 1. COMPARISONS OF DIFFERENCES LEARNING STRATEGIES AMONG OF E-COURSE TECHNOLOGIES

\begin{tabular}{|c|c|c|c|c|c|c|c|c|c|}
\hline 1 - Collaborative Learning Strategy: & & $\mathrm{X} 2=3.99$ & $\mathrm{X} 2=4.11$ & $\mathrm{X} 3=4.08$ & $\mathrm{X} 4=4.22$ & $X 5=3.99$ & $\mathrm{X} 6=4.11$ & $X 7=4.09$ & $\mathrm{X} 8=4.13$ \\
\hline 2 -A Problem Solving Strategy: & $\mathrm{X} 1=3.99$ & & $7.56^{* *}$ & 0.389 & $4.02^{* *}$ & 1.509 & $3.209^{* *}$ & 0.405 & $2.15^{*}$ \\
\hline 3-Discussion Strategy & $\mathrm{X} 2=4.11$ & & & $7.55^{* *}$ & $3.29^{* *}$ & $6.1^{* *}$ & $4.23^{* *}$ & $11.42^{* *}$ & $3.7^{* *}$ \\
\hline 4 - Collaborative Learning Strategy: & $\mathrm{X} 3=4.08$ & & & & $3.94 * *$ & 1.23 & $3.02^{* *}$ & 0.142 & 1.92 \\
\hline 5- Active learning Strategy: & $\mathrm{X} 4=4.22$ & & & & 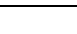 & $2.69^{* *}$ & 0.875 & $4.05^{* *}$ & 1.07 \\
\hline 6- Learning strategy based on the project & $\mathrm{X} 5=3.99$ & & & & & -- & 1.79 & 1.8 & 0.994 \\
\hline 7 - interactive Electronic Lecture: & $\mathrm{X} 6=4.11$ & & & & & & -- & $2.93^{* *}$ & 0.39 \\
\hline 8-Visual Thinking Strategy: & $\mathrm{X} 7=4.09$ & & & & & & & -- & $1.97 *$ \\
\hline 9 - Discovery Learning Strategy: & $\mathrm{X} 8=4.13$ & & & & & & & & -- \\
\hline
\end{tabular}

\section{Integrating Internet Tools For Designing E-course architecture.}

Any strategy to build online learning has to be to rely on a set of tools to make e-courses to achieve these Intelligent ecourses Management Architectures these tools should include the Integration of Internet tools: synchronous conference, forum discussions, annotation tool, web-cast, Rich Site Summary RSS, wiki web, weblog, web-quest, email, mail list, mail form, e-news, news-groups, digital library, reference tools, quizzes tool, Frequently Asked questions FAQ, searching tool, colander, Guestbook, Visitor list, Glossary tool, Album photo and Map site [Appendix 1]. It should be noted that the steps or processes that employ a proposed intelligent architecture for e-courses management must be flexible so that the amendment by each teacher in harmony with the nature of each activity and the nature of the learning environment via the Internet tools and patterns of interaction, but it must be governed by the general format of these steps for the proposed the activity by focusing on the components of active learning (input- the process of conversion-output) [12].

D. A Proposed Web-based adaptive Learning System (intelligent e-course) should have the Following Functions:

Curriculum sequencing: providing students with the most suitable sequence of information units of learning tasks (e.g., questions, problems, etc.) to work through. Curriculum sequencing helps the pupil to find an "optimal path" through the learning content.
Presentation: giving learning materials to students by constructing e-learning web pages continuously and automatically.

Navigation support: helping students and giving the student the choice of the next step for getting the information and knowledge item should be learned and determine the next problem to be solved.

Problem solving support: providing the student with intelligent help at each step of problem solving by giving a hint to execute the next step. Such a system should be able to monitor the actions of the student, understand them, and use this understanding to provide help and to update the student model.

Intelligent Solutions: providing the students the optimum answers after intelligent analysis to guide the student with the solution which is correct and determine the place of wrong or incomplete and which missing or incorrect knowledge which cause the error.

Example-based Solving support: getting the students the examples that guide them to solve new problems.

Collaboration support: using the system's database about different students in different models to consist a matching collaborative group. 


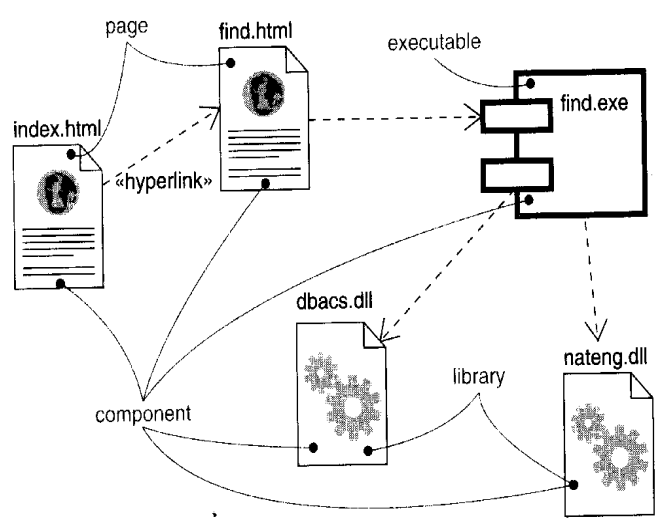

Figure 1. Architecture Modeling of a Web-Based Learning System [13]

The intelligent architecture strategy for e-courses management is divided into seven sub-strategies. The researcher were able to develop a general framework for building e-course site, and this to be a framework of (20) educational activity has been formulated to achieve the proposed (intelligent architecture for e-courses management), (22) is a Internet tools that can be achieved through such activities and educational strategies (discussion forum, discussion rooms, e-library (electronic archive, the library of articles, photo library), search system, a list of visitors, FAQ, Guestbook, codes, Glossary, Site Map, Photo Gallery, a news reader, news, self-evaluation comments, the Agenda for Action (the diary). This is in addition to the identification of (8) patterns of interaction within the educational site, was as follows:

- Learner-Learner Interactive

- Learner-Instructor Interactive

- Instructor-Learner Interactive

- Learner-Content Interactive

- Instructor-Content Interactive

- Learner-Self Interactive

- Learner-Interface Interactive

- Learner-Tools Interactive

\section{Design A Web Based LeARning System Using OBJECT ORIENTED SYSTEM DEVELOPMENT (OOSD)}

\section{A. Object Oriented System Development (OOSD) Approach}

The OOSD approach creating a lot of helpers that take on an active role, that form a community whose interactions become the applications and Einstein College of Engineering.

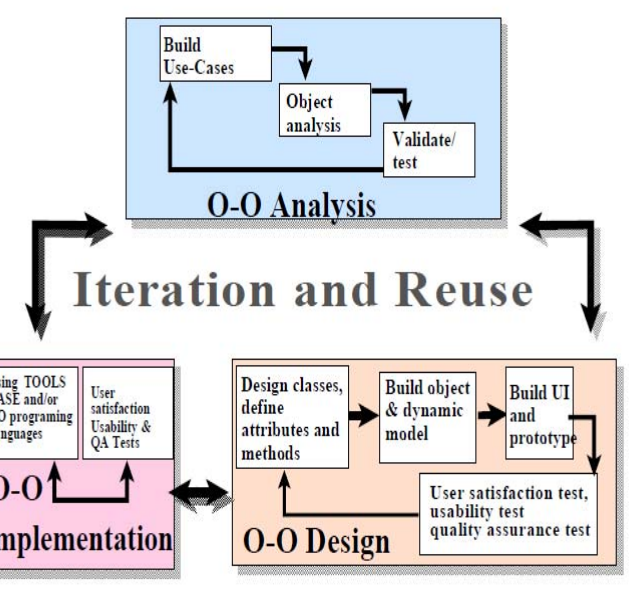

Figure 2. Sequence Diagram For e-Learning Web-Based System Using OOSD

The requirement of the specification and the design of the web-based should include both: Sun C. Yong and Zhiming Lium, 2003

- E-learning system. To concentrate on lessons, examination, homework and

- Learning activity Questions. The problems of evolution and maintenance of e- learning systems should combine the OO database such as SQL to store the information of persons and course material.

\section{LOGIC.'AL IMIPLEMENIA (DESIGN) TION TIEW SIEY"

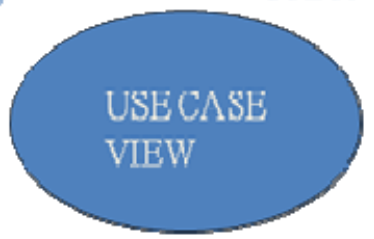 \\ PROCESS VIEVI \\ DEPLOKAEN TYIEW}

Figure 3.: Object Oriented Modeling of Software Systems: OO modeling [15]

\section{B. Object Oriented Software Modeling:}

Researcher has adopted the model of object oriented model that can be used in place of the e-course design. The researcher have followed the following steps, respectively, in the construction of e-course (the stage of analysis - the design phase - the development phase - the stage of application and evaluation.

The design phase of education, which has the construction of educational strategy intelligent architecture for e-courses management, should be identified in the light of the procedures and the various steps to provide educational content and to identify ways to provide educational activities and interactions with e-courses: [15]

- to provide electronic educational content with more one way taking into account the individual differences.

- to allow e-course for students and contribute in building the content within the site. 
- To link students to many other sites that provide the content of linked networks.

- $\quad$ to employ e-learning Banai grounds in the provision of diverse contents.

C. Software Process [16] [21]

The software development process Object Oriented Systems Development Life Cycle should include the following.

- Building high-quality software

- Object-oriented systems development

- Use-case driven systems development

- Prototyping

- Rapid application development

- Component-based development

- Continuous testing and reusability

So, it we need to maintain

- Building blocks: objects and classes

- Object: identity, state and behavior

- Class: description of a set of similar objects

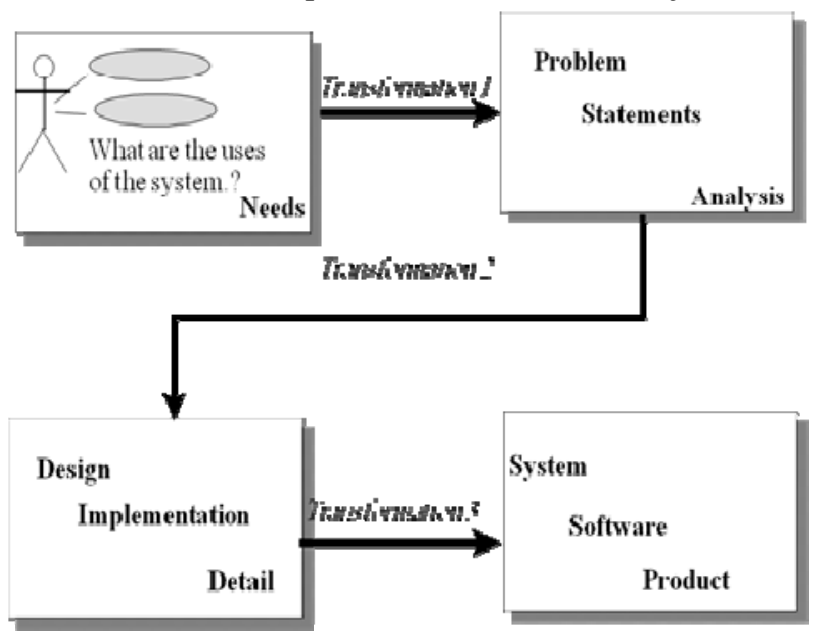

Figure 4. Overview Component Diagram
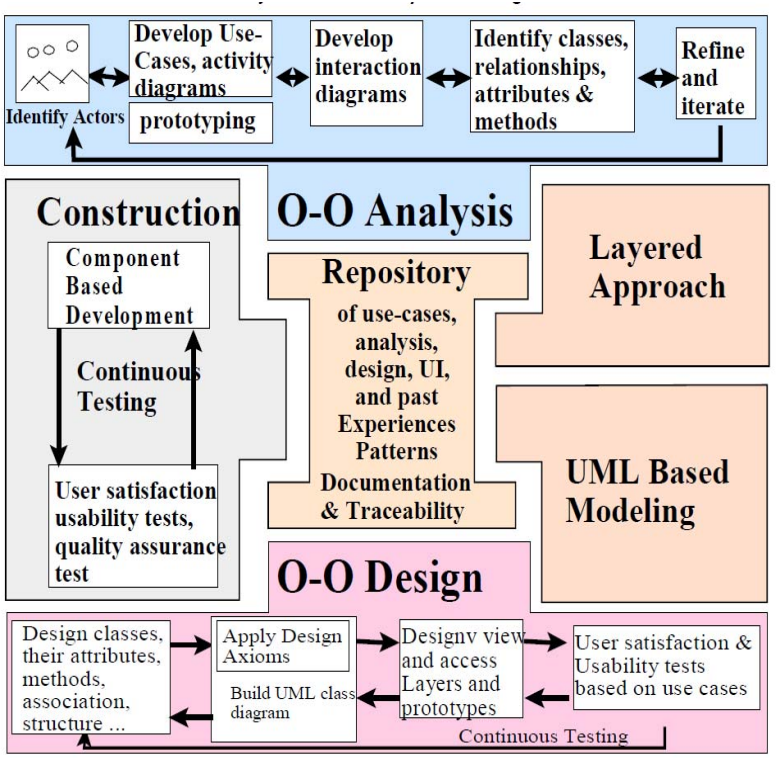

Figure 5.: Web-Based Learning Component Diagram USING UML

"The main problem with the above models is a lack of interrelationship. Data Flow Diagrams, Entity Relationships models, and narrative text descriptions of the system all have very separate ways of describing the system but they have little influence on each other [16]. Entity Relationships are coming from the database community and Data Flow Diagrams is coming from the structured programming world [17]. These systems are can only represent one very specific view of the system and leave the integration to the modeler. So UML is partially built upon these systems, because UML is an enhanced form of OMT (Object Modeling Technique) which is an enhanced form of ER diagrams and UML is specifically designed for modeling object-oriented systems and it integrates these modeling techniques coherently and hopefully will be able to overcome these problems [18]"

\section{Presentation AND Discussion of the RESEARCH RESULTS}

\section{A. Homogeneity of the experimental groups:}

For the calculation of the homogeneity of the students innovative thinking, many measurement of the pretest groups, such as the arithmetic average was calculated, the standard deviation, and the ratio of degrees of $\mathrm{F}$ test of the two groups in the pilot test of the measurement, as shown in table (2).

TABLE 2. Differences BetweEn The two groups in the Pilot EXPERIMENTS TO TEST STUDENT INNOVATIVE THINKING

\begin{tabular}{|c|c|c|c|c|c|c|}
\hline \multirow[t]{2}{*}{$\begin{array}{l}\text { No. } \\
\text { of each } \\
\text { group }\end{array}$} & \multicolumn{2}{|c|}{$\begin{array}{l}\text { The first pilot } \\
\text { (initial group) } \\
\text { Traditional } \\
\text { network web } \\
\text { site }\end{array}$} & \multicolumn{2}{|c|}{$\begin{array}{l}\text { Second experimental } \\
\text { group } \\
\text { e-course }+ \text { proposed } \\
\text { intelligent architecture } \\
\text { for e-courses using OO }\end{array}$} & \multirow[t]{2}{*}{$\begin{array}{c}\text { "T ". } \\
\text { Calc } \\
\text { ulate } \\
\text { d }\end{array}$} & \multirow[t]{2}{*}{$\begin{array}{l}\text { The } \\
\text { level } \\
\text { of } \\
\text { signifi } \\
\text { cance }\end{array}$} \\
\hline & $\begin{array}{l}\text { Arith } \\
\text { metic } \\
\text { mean }\end{array}$ & $\begin{array}{c}\text { Stand } \\
\text { ard } \\
\text { devi } \\
\text { ation }\end{array}$ & $\begin{array}{c}\text { Arithmetic } \\
\text { mean }\end{array}$ & $\begin{array}{c}\text { Standa } \\
\text { rd } \\
\text { deviat } \\
\text { ion }\end{array}$ & & \\
\hline 20 & $18 . .11$ & $3 . .81$ & 28.22 & 5.31 & $\begin{array}{l}8.11 \\
2\end{array}$ & $\begin{array}{l}\text { Signif } \\
\text { icant }\end{array}$ \\
\hline
\end{tabular}

The results indicated statistical treatment as set out in the table 2 that the ratio $F$ test $(1,705)$ are not significant at the level of statistical significance (0.01), and this meant that there was no statistical differences in function between the groups, which indicates the homogeneity of the students to test the levels of innovative thinking before the experiment.

$B$. The Effectiveness of the Proposed Intelligent Web-based Architecture Using OO in Students Creative thinking

To verify the effectiveness of the proposed strategy to increase creative thinking (fluency + originality + flexibility) associated with the content of educational networks, the calculation of significant differences among the middle levels of the two members of the pilot, in the application of dimensional test innovative thinking, and has been shown to reach the scale of results in table 3 .

Table (3) illustrated the capacity of the high innovative thinking among students in the experimental group used the second e-course depends on the electronic educational strategy proposed in the initial comparison of the experimental group used the website without the traditional educational strategy, with an average degree of the second experimental group students (28.22), while the average degree of the initial students of the experimental group 
(18.11), and amounted to "T." calculated (8.112), and to disclose the value of " $\mathrm{t}$ " in statistical table, we find it equal to (2.76) and thus be a " $t$ " greater than the calculated " $T$ " in the statistical table the level of significance $(0.01)$ and 38 degrees of freedom, that is, a statistical function.

Thus being statistically significant in favor of the highest in the medium, a second experimental group (web site + proposed intelligent architecture for e-courses management), where the arithmetic average with (28.22) by an increase from the first experimental group (the traditional site of the Internet) is (10.11).

TABLE 3. The ARITHMETIC MEAN, StANDARD DEVIATION AND THE VALUE OF "T" FOR THE AVERAGE SCORES OF TWO EXPERIMENTAL GROUPS IN THE PILOT OF THE MEASUREMENT OF INNOVATIVE THINKING

\begin{tabular}{|c|l|l|l|l|l|}
\hline $\begin{array}{c}\text { Source of } \\
\text { variation }\end{array}$ & Squares & $\begin{array}{c}\text { Degrees } \\
\text { of } \\
\text { freedom }\end{array}$ & $\begin{array}{c}\text { Average } \\
\text { squares }\end{array}$ & $\begin{array}{c}\text { F } \\
\text { value }\end{array}$ & $\begin{array}{c}\text { The level of } \\
\text { significance }\end{array}$ \\
\hline $\begin{array}{c}\text { Between } \\
\text { groups }\end{array}$ & 9.121 & 1 & 8.911 & \multirow{2}{*}{1.812} & $\begin{array}{l}\text { Insignificant } \\
\text { at } \\
(0.001)\end{array}$ \\
\cline { 1 - 3 } $\begin{array}{c}\text { Within } \\
\text { groups }\end{array}$ & 141.234 & 38 & 6.008 & & \\
\hline Total & 149.571 & 39 & & & \\
\hline
\end{tabular}

\section{Interpretation of the results:}

Researcher attributed this discrepancy between the experimental group II (the site of an electronic e-course + the proposed intelligent architecture for e-courses management, and the first pilot sites (the traditional e-course, to the diversity of educational strategies within the e-course, the second experimental group, and therefore the employment of the tools used the site contributed to the effective functioning in the induction of the educated and their participation in many of the positions that made them learn to express their ideas and opinions freely (discussion forum, discussion room), as well as the adoption of the theory of building the site in the formulation and submission of content that has been submitted according to the theory that the provision of different patterns have helped to enrich the educational attitudes, Consequently, the development of fluency - flexibility - originality of the research sample of students, which also affected the delivery of multi-patterns and the provision of content, as well as the interest of a proposed intelligent architecture for e-courses management used in the construction of the e-courses of a number of electronic tools that provoke the learner to participate and contribute to the content of the site (such as the library of articles, helped to develop the capacity of fluency, flexibility and originality to the learners, the use of some of the tools that encourage learners to express themselves and their views, such as the Code and the Guestbook tool has helped the development of innovative thinking ability of students to the research sample.

Table (4) shows that the higher average grades of students at the second experimental group used the site designed in the light of the proposed(intelligent architecture for ecourses management)when compared to the initial pilot group used the traditional course, with an average degree of the second experimental group students (82.80), while average degree of the initial students of the experimental group (58.44), and amounted to "T." calculated $(4,129)$, and to disclose the value of " $t$ " statistical table, we find it equal to (2.76) and thus be a "T." calculated the largest of the "t." statistical table at the level of significance (0.01) and 38 degrees of freedom, that is, a statistical function.

TABLE 4. The ARithmetic Mean, StAndard DeViation AND The VALUE OF "T" For THE AVERAGE DEGREE OF TWO EXPERIMENTAL GROUPS

\begin{tabular}{|c|c|c|c|c|c|}
\hline \multicolumn{2}{|c|}{$\begin{array}{c}\text { First experimental } \\
\text { group } \\
\text { Traditional course }\end{array}$} & \multicolumn{2}{|c|}{$\begin{array}{l}\text { e-course }+ \text { proposed } \\
\text { intelligent architecture } \\
\text { for e-courses using OO }\end{array}$} & \multirow[t]{2}{*}{$\begin{array}{l}\text { "T". } \\
\text { Calcula } \\
\text { ted }\end{array}$} & \multirow[t]{2}{*}{$\begin{array}{c}\text { The } \\
\text { level } \\
\text { of } \\
\text { signifi } \\
\text { cance }\end{array}$} \\
\hline $\begin{array}{l}\text { Arithmet } \\
\text { ic } \\
\text { average }\end{array}$ & $\begin{array}{c}\text { Standar } \\
\mathrm{d} \\
\text { deviati } \\
\text { on }\end{array}$ & $\begin{array}{l}\text { Arithmet } \\
\text { ic } \\
\text { average }\end{array}$ & $\begin{array}{l}\text { Standard } \\
\text { deviation }\end{array}$ & & \\
\hline .58 .44 & 8.21 & 82.8 & 5.1 & 4.129 & $\begin{array}{l}\text { Signif } \\
\text { icant }\end{array}$ \\
\hline
\end{tabular}

The proposed education strategy focused on fast feedback provided to learners and that a variety of tools can be a rapid answer to the queries of students, resulting in a kind of psychological comfort of the learner's result of the rapid response of the site. Interested in the evaluation system proposed educational strategy to inform students on the basis as a tool in the Web Quest, the proposed strategy also has the immediate announcement of the results and correct the errors of the educated and informed of the calendars as a tool in the short, which helped to create the positive trends of the learners which is agreed with result mentioned in [12] [9].

- Encouraged the proposed dialogue and discussion between the various parties without the need for confrontation and face-to-face, thereby removing the fear that may be felt by some learners and, consequently, the formation of positive trends.

- The unique and diverse methods used to make the content more attractive had the greatest impact in the hearts of students, and the development of positive attitudes to them. This is agreed with (Joonho Do, Lunkying Lee, [20] On line

\section{CONCLUSIONS}

The intelligent architecture strategy for e-courses management divided into seven sub-strategies. The researcher were able to develop a general framework for building e-course, and the set the framework of (20) educational activities which has been formulated to achieve the proposed intelligent architecture for e-courses management, (22) Internet tools that can be achieved through activities and educational strategies (discussion forum, discussion rooms, e-library (electronic archive, the library of articles, photo library), search system, a list of visitors, FAQ, Guestbook, codes, Glossary, Site Map, Photo Gallery, a news reader, news, self-evaluation comments, the Agenda for Action (the diary). The strategy also considered the identification of (8) patterns of interaction within the 
educational site, were as follows:

1. Learner-Learner Interactive

2. Learner-Instructor Interactive

3. Instructor-Learner Interactive

4. Learner-Content Interactive

5. Instructor-Content Interactive

6. Learner-Self Interactive

7. Learner-Interface Interactive

8. Learner-Tools Interactive

This agrees with Sun C. Yong and Zhiming Lium (2003) who ensured the requirement of the specification and the design of the web-based should include both:

- E-learning system. To concentrate on lessons, examination, homework and

- Learning activity Questions. The problems of evolution and maintenance of e- learning systems should combine the OO database such as SQL to store the information of persons and course material. http://www.objectsbydesign.com/tools/umltools_byCo mpany.html).

The researcher confirmed that the proposed intelligent architecture depends on each stage requesting. The educated group of activities must be performed, through a set of tools (e-mail - Conference debate - discussion forum - and search - Virtual Library), as that in the previous steps the learner interacts with the components of active learning are the three inputs, respectively, of the articles, pictures and experts and peer learning, and sources of information through research, the conversion process, which has been through the construction of concepts through discussion, which included the analysis and e-course-making, translation, summary, or Calendar the findings of the learners (the review and development), followed by solution of the problem, and output, respectively, and present a report of an article.

\section{REFERENCES}

[1] Sun C. Yong and Zhiming Lium, Apply Object-Orientation and UML to the Development of Web-based Learning System, UNU/IIST Report No. 274T, International Institute for Software Technology, March 2003 , http://www.iist.unu.edu/www/docs/techreports/reports/report274.pdf

[2] Adar Eytan Zhang, et al : Implicit Structure and the Dynamics of Blogspace. HP Labs. Retrieved March 21, 2004

[3] Bernie Dodge: Active Learning on the Web, 2000, pp1-20.

VI. Charles Y. Y. Cheng, Jerome Yen: Virtual Learning Environment (VLE): A We Based Collaborative Learning System, IEEE Conference, 1998, p3.

[4] Elizabeth Stacy: Learning Links Online: Establishing Constructivist and Collaborative Learning Environments, ASET conference, Deakin University, 2002.
[5] Eugenia M.W.Ng \& Ada W.W.Ma: An Innovative Model To Foster Web Based Collaborative Learning, Information Science, June 2002, p3.

[6] Florida State University: Using Course Websites as Instructional Tools (A Guide to Teaching and Learning Practice, 2006,p8. http://edweb.sdsu.edu/people/bdodge/Active/ActiveLearning.html [5/4/2007]

[7] Holland: Designing an Online Literacy Interface, The Annual Conference of the British Educational Research Association, University of Exeter, England, 12-14 September 2002.

[8] http://ctl.sdsu.edu/guide/10-Course_Websites.pdf [10/8/2007]

[9] http://loisscheidt.com/linked/bibliographies/Weblog_and_Blog_Bibli ography.pdf [19/8/2007]

[10] http://www.lalc.k12.ca.us/humanitas/neh/artbasedlesson_visual.html [21/5/2007]

[11] http://www.objectsbydesign.com/tools/umltools_byCompany.html

[12] http://www.sop.inria.fr/acacia/personnel/Sylvain.Dehors/SWEL@AIED-DehorsFaronStromboniGiboin short.pdf [1/9/2007].

[13] Illinois Online Network: Instructional Strategies for Online Course, University of Illinois, 2007, p4.

[14] Joonho Do, Lunkying Lee : World Wide Web in the Virtual Classroom, $1998 . \quad$ On line: http://www.pandora.nph_arch/01998 dec3/http:www.education ust.e du.au//projects/vol3/do.html [12/10/2006]

[15] Joseph Bergin: Teaching on The Wiki Web, ITICSE'02 Conference, Denmark, June 24-26, 2002, p15. http://www.cs.kent.ac.uk /national/EPCOS/acm-eg.pdf [1/8/2007]

[16] Lance J. Richards, Kim E. Dooley, James R.Linder: Online Course Design Principles, Taxes A\&M University, USA, 2004, pp 105-107.

[17] M.R. Koivunen: Annotea Project: Overview, 2004, p1. On line: http://www.w3.org/2001/Annotea/ [1/9/2007].

[18] Mary Lenihan: Visual Thinking Strategy (VTS) - A Looking Strategy for the Visual Arts, 2001.

[19] Meng Hong Tay, et al.,: Discourse-Based Learning Using a Multimedia Discussion Forum, IEEEXplore Electronic Periodicals, 2007, p1.On line: http://ieeexplore. ieee.org/Xplore/login.jsp?url=/iel5/8445/26602/01185928.pdf $[1 / 8 / 2007]$

[20] Neil Harris, Maria Sandor: Developing Online Discussion Forum Student Centered Peer E-Learning Environments, Proceedings ASCILITE Conference, Singapore, $2007 \quad$,p5. http://www.ascilite.org.au/conferences/singapore07/procs/harris.pdf $[12 / 8 / 2007$

[21] Sandy Scragg: The Webquest Model, 2007, pp, 1-3. http://www.sandyscragg.com/webQhandout.pdf [1/8/2007]

[22] Shalni Gulati: Constructivism and Emerging Online Pedagogy, City University, London, 2004, p 18.

[23] Sylvain Dehors, etal.,: Semi-Automated Semantic Annotation of Learning Resources by Identifying Layout, 2005, p2.

[24] UML

Diagrams, http://tac.eecs.umich.edu/proj/docs/redesign/auctioneerUML.html

[25] Ya Ling Lee: Integrating Constructivist Approaches In E-Learning To Enhance Mathematical Self-Study, The Mathematics Education Into The 21st Century Project, University Teknologi Malysia, 2005.

[26] Roshan Bangera, Bill Randm Reverse Engineering and UML: A Case Study of AuctionBot, EECS 581, http://129.2.113.2/ wrand/papers/UMLFinal-rev.pdf.

[27] Einstein College of Engineering, OBJECT ORIENTED ANALYSIS AND DESIGN, CS1402, without date, http://www.einsteincollege.ac.in/Assets/Department/Lecturer\%20note s/CSE/UG/CS\%201042\%20OBJECT\%20ORIENTED\%20ANALYSI S\%20AND\%20DESIGN.pdf 
APPENDIX 1 : INTEGRATING INTERNET TOOLS FOR THE PROPOSED E-COURSE ARCHITECTURE

\begin{tabular}{|c|c|c|c|c|}
\hline No & E-course Tools & Description & S.D. & $\begin{array}{l}\text { Mean } \\
\mathrm{X}\end{array}$ \\
\hline 1. & $\begin{array}{l}\text { (Synchronous } \\
\text { :conferences) }\end{array}$ & rely on a direct dialogue or Chat, and videoconferencing, and audio conferences. & 0.89 & 4.26 \\
\hline 2. & :(Forum Discussion) & $\begin{array}{l}\text { it is the most liberal of the educated who are afraid of the discussions and face-to-face, They } \\
\text { are working to improve the learners understanding of knowledge. }\end{array}$ & 0.98 & 4.11 \\
\hline 3. & :(Annotation Tool) & $\begin{array}{l}\text { it illustrates an important idea or to add new information related to content and information } \\
\text { given to the appendix as the site of the data (Metdata). }\end{array}$ & 0.88 & 4.02 \\
\hline 4. & :(Web Cast) & $\begin{array}{l}\text { Web cast meant to send pictures or live television broadcasts across the web, this tool aims to } \\
\text { events directly from the location of realism in real time to the learners via the Internet } \\
\text { environments. }\end{array}$ & 0.82 & 4.36 \\
\hline 5. & $\begin{array}{c}\text { :(RSS) } \\
\text { Rich Site Summary }\end{array}$ & $\begin{array}{l}\text { is news reader tool. This tool aims to inform the learner information has been updated, by } \\
\text { important, Title and Summary }\end{array}$ & 0.74 & 3.29 \\
\hline 6. & :(Wiki web) & $\begin{array}{l}\text { A Dynamic web site, interactive, as well as enabling visitors to add a new page name under } \\
\text { any name he selects, this tool allows teacher to contact learners synchronous communication } \\
\text { that does not also put the dates of the study and provide opportunity for learners to add or } \\
\text { amendment according to their findings from the knowledge }\end{array}$ & 1.01 & 3.88 \\
\hline 7. & :(Weblog) & $\begin{array}{l}\text { enables the learner to add a new page written by the thoughts or new ideas resulting from the } \\
\text { examination of the course }\end{array}$ & & \\
\hline 8. & :(Web quest) & $\begin{array}{l}\text { The tool consists of Investigation (Web quest) from the six major components: respectively } \\
\text { Introduction - Mission - Operations - Sources of information - Calendar - Conclusion }\end{array}$ & 0.85 & 4.15 \\
\hline 9. & :E-mail) & $\begin{array}{l}\text { enable users to send and receive messages among themselves regardless of the range of } \\
\text { visual and print messages, pictures or audio files or video files. }\end{array}$ & 0.78 & 4.23 \\
\hline 10. & :(Mail list) & $\begin{array}{l}\text { Also called the group, which e-mail addresses that can pass messages to or used by the } \\
\text { participants in the debate (s), including on specific topics. }\end{array}$ & 1.02 & 3.95 \\
\hline 11. & :(Mail form) & $\begin{array}{l}\text { enable the learner in the synchronous learning environment via the Internet to send queries to } \\
\text { the teacher, as well the teacher is responsible for building the learning environment }\end{array}$ & & \\
\hline 12. & :(E-News) & $\begin{array}{l}\text { enables learners to participate in a variety of groups in a global concerns or areas of life such } \\
\text { as medicine, education and others.. }\end{array}$ & 0.78 & 4.17 \\
\hline 13. & News-groups & $\begin{array}{l}\text { used for the purpose and regulatory, as they attract and facilitate the consideration of the } \\
\text { learner to access all that is new and the subject of learning }\end{array}$ & 0.98 & 3.97 \\
\hline 14. & Digital Library & $\begin{array}{l}\text { enhancing the online learning environments; they provide a stock of reliable information that } \\
\text { will help the learner in the construction of knowledge. }\end{array}$ & 0.74 & 4.11 \\
\hline 15. & :(Reference Tool) & $\begin{array}{l}\text { contain references back to the teacher or the author of e-course, may be a reference books } \\
\text { and scientific articles, letters or a group of links enrichment. }\end{array}$ & & \\
\hline 16. & :(Quizzes Tool) & $\begin{array}{l}\text { Is a tool for self-evaluation of the learner, they measure the ability of the learner to recall } \\
\text { knowledge and understanding; as they contain a range of diverse substantive questions such } \\
\text { as right and wrong and choose from multiple requests and questions to answer short - and } \\
\text { associated content are closely linked. }\end{array}$ & 0.93 & 4.42 \\
\hline 17. & $\begin{array}{l}:(\mathrm{FAQ}) \\
\text { (Frequently Asked } \\
\text { Qwestions) }\end{array}$ & $\begin{array}{l}\text { A sense of frequently asked questions, and teacher work through this tool to compile queries } \\
\text { and questions that are repeated continuously educated and answers in the database. }\end{array}$ & 0.69 & 4.32 \\
\hline 18. & :(Searching tools) & $\begin{array}{l}\text { assist the learner in the search for information within the learning environment on the } \\
\text { Internet (the site of education) }\end{array}$ & 0.82 & 4.06 \\
\hline 19. & :(Calendar) & $\begin{array}{l}\text { aims to identify the possibility of the learner on the current time or date at date is chosen days } \\
\text { of the week }\end{array}$ & 0.91 & 4.06 \\
\hline
\end{tabular}


International Journal of Engineering and Technology Vol. 1, No. 4, October, 2009

ISSN: 1793-8236

\begin{tabular}{|c|c|c|c|c|}
\hline 20. & :(Guestbook) & $\begin{array}{l}\text { allow learners or educational web site visitors to book their views and comments and } \\
\text { feedback on the web site }\end{array}$ & & \\
\hline 21. & :(Visitor List) & $\begin{array}{l}\text { aims to continue to the web site with each other, as it is a mailing list of the learners or } \\
\text { members of the participants in the learning-by-site education. }\end{array}$ & 0.82 & 4.18 \\
\hline 22. & :(Glossary Tool) & $\begin{array}{l}\text { definitions of terms common in the educational content of the it contains a list of } \\
\text { environment via the Internet learning }\end{array}$ & 1.22 & 3.98 \\
\hline 23. & :(Album Photo) & $\begin{array}{l}\text { contain a database of o learning, it is integrated with the images of educational content and } \\
\text { help learners in building their own knowledge }\end{array}$ & 1.05 & 3.7 \\
\hline 24. & :(Map Site) & $\begin{array}{l}\text { Planning for a Web site containing the components of the tools (discussion forum - Rooms } \\
\text { Discussion - Search - Calendar - ....) Library and the elements of the educational content } \\
\text { provided through the lectures or lessons-learning. }\end{array}$ & 0.96 & 91. \\
\hline
\end{tabular}

